ДУХОВНИЙ ПОТЕНЦІАЛ ТА ОСОБИСТІСНІ ЯКОСТІ МАЙБУТНІХ ФАХІВЦІВ-ПСИХОЛОГІВ (ЕМПІРИЧНЕ ДОСЛІДЖЕННЯ НА БАЗІ ОНУ ІМЕНІ І.І. МЕЧНИКОВА)

\author{
SPIRITUAL POTENTIAL AND PERSONAL QUALITIES \\ OF FUTURE PSYCHOLOGISTS (EMPIRICAL STUDY \\ ON THE BASIS OF ONU NAMED AFTER I.I. MECHNIKOV)
}

УДК 159.937:94:246.3:159.91

DOI https://doi.org/10.32843/2663-

5208.2020.13-2.6

\section{Данілова О.С.}

к.психол.н., доцент кафедри клінічної психології

Одеський національний університет імені І.І. Мечникова

щерблюк О.І.

бакалавр психології

Одеський національний університет

імені І.І. Мечникова

\begin{abstract}
У сучасному суспільстві особливо гостро стоїть питання про виховання людини, самовдосконалення, духовне й особистісне зростання. у статmі розглядається основний зміст поняття «духовний потенціал» як основи для осмислення і регуляціі людської поведінки та діяльності у всіх ї формах та проявах. Наголошується, що регуляція професійної діяльності майбутніх фрахівиів-психологів засобами иінностей виступає одним із найбільш значущих чинників профресійної придатності та їх просресіоналізму як практичних психологів. Ціннісні аспекти сучасної психологічної практики зумовлені цілою низкою важливих причин, пов'язаних насамперед із наявною соціально-економічною ситуацією, а також з появою нових психотехнологій та практик надання фрахової просресійної психологічної допомоги. у чій статті проводиться аналітичний огляд літератури на таку проблематику крізь призму фрілософрсько-психологічного аспекту. Авторами було визначено поняття «духовний потенціал» особистості і проведено емпіричне дослідження на базі ОНУ імені I.I. Мечникова.

у дослідженні використовувались стандартизовані методики відповідно до мети. Завдяки отриманим результатам було розроблено авторський опитувальник. Виявлено, що детермінантами духовного потенціалу виступають такі особливості особистості, як здатність до активного аналізу скоєних вчинків, конгруентність, емпатія та любов до близьких, здатність до самоконтролю та відсутність напруження у повсякденному житті, позитивний настрій, життєва активність, активність соціального життя, відчуття оптимістичної перспективи. Таким чином, теоретична розробка підходів емпіричного дослідження до професіонального відбору, на наш погляд, потребує подальшого вивчення як сукупність виявлення актуальних та потенційних характеристик особи як суб'єкта трудово діяльності в галузі психології.
\end{abstract}

Ключові слова: духовний потенціал особи стості, духовність, конгруентність, інтроспекція, ціннісні орієнтації, емпатія.

In modern society, the issue of human education, self-improvement, spiritual and personal growth is particularly acute. The article considers the main meaning of the concept of "spiritual potential" as a basis for understanding and regulating human behavior and activities in all its forms and manifestations. It is emphasized that the regulation of professional activity, future specialists of psychologists, means of values is one of the most important factors of professional suitability and their professionalism as practical psychologists. The value aspects of modern psychological practice are due to a number of important reasons primarily related to the current socio-economic situation, as well as the emergence of new psychotechnologies and practices of providing professional psychological care.

This article provides an analytical review of the literature on this issue through the prism of the philosophical and psychological aspect. The authors defined the concept of spiritual potential of the individual and conducted an empirical study on the basis of ONU named after I.I. Mechnikov. The study used standardized techniques in accordance with the purpose. Thanks to the obtained results, an author's questionnaire was developed. It was found that the determinants of spiritual potential are such personality traits as the ability to actively analyze actions, empathy, ability to self-control and lack of stress in everyday life, positive mood, vital activity, social life activity, a sense of optimism. Thus, the theoretical development of approaches to empirical research to professional selection, in our opinion, requires further study as a set of identifying current and potential characteristics of the person as a subject of work in the field of psychology. Key words: spiritual potential of personality, spirituality, congruence, introspection, value orientations, empathy.
Актуальність проблеми полягає в тому, що натепер в Україні ми бачимо, що цінуються психологи-професіонали в різних галузях, які здатні на високому рівні виконувати різноманітні професійні обов'язки.

Дослідження поняття «духовний потенціал» особистості полягає у систематизації відомостей про духовність з різних джерел, опису їі феноменологічних проявів; вивчення цілісного феномена людини в зв'язку зі становленням «простору-існування і розвитку людської душі», розгляду звичних категорій у тональності нових методологічних орієнтирів; визнанням різноманіття, суперечливості, складності людини та її внутрішнього життя; дослідження засноване на методології філософсько-богословського аспекту, на історично-психологічному аспекті та проведених емпіричних дослідженнях серед студентів-психологів.

Об'єкт дослідження - соціально-психологічний феномен духовного потенціалу фахівців-психологів. 
Предмет дослідження - духовний потенціал і особистісні якості майбутніх фахівців-психологів.

Мета дослідження полягає у визначенні чинників духовного потенціалу та особистісних якостей майбутніх фахівців-психологів під час навчання у ВНЗ.

Методи дослідження: метод герменевтики, метод інтроспекції, бесіда, контентаналіз, лонгітюд, синтез, узагальнення.

Методики дослідження: «Шкала емоціонального відгуку» (Balanced Emotional Empathy Scale - BEES) Альберта Меграбяна (Albert Mehrabian), модифікована Н. Епштейном; опитувальник Кеннета Томаса (Kenneth Thomas) «Визначення способів регулювання конфліктів»; «Методика оцінки рівня товариськості» В. Раховського; авторський опитувальник «Прагнення до світла», присвячений духовноособистісному росту фахівця-психолога.

Інтерес до вивчення механізмів формування і розвитку особистісних якостей простежується в низці психологічних досліджень таких авторів, як: І. Белявський, Т. Зенкевич-Євстигнєєва, І. Андрєєва, О. Бондаренко, І. Вачкова, С. Дерев'янко, Є. Ільїн, М. Амінов, О. Бодальова, О. Власова, В. Карандашева, О. Саннікова, Н. Чепелєва та ін. К. Абульханова-Славська, С. Максименко, В. Масколенко, С. Рубенштейн, О. Данілова розглядали і роблять акцент на необхідності підвищення суб'єктивності життєдіяльності. А. Ацупов, Д. Бакум, С. Гінзер, своєю чергою, робили акцент на навчанні молодих людей та вмінні розпоряджатися своїм життям, робити його предметом власної свідомості та волі.

Проблема духовності $€$ предметом уваги українського психолога М. Боришевського, який визначає, що: «Духовність - багатовимірна система, складниками якої $€$ утворення у структурі свідомості та самосвідомості особистості, в яких віддзеркалюються її найбільш актуальні морально релевантні потреби, інтереси, погляди, ставлення до інших людей, до себе самої, що стали суб'єктивно значущими регуляторами активності» [2].

На думку вченого М. Савчина: «Духовний потенціал людини - це сукупність її духовних, душевних (психічних) і фізичних сил та властивостей, що визначають ї̈ стосунки з Богом, людьми і світом та її життя. Людина з високим духовним потенціалом, яка має догматичну свідомість... Основним сенсом її життя $€$ вдосконалення себе і світу» [6].

Діагностика духовного потенціалу пов'язана з вивченням цілісної життєдіяльності та подій життя особистості, з вивченням її біографії. Для визначення можливих шляхів духовного розвитку людини суттєво знати особливості самосвідомості, спрямованість особистості, її ціннісні орієнтації, творче начало.
Кожна людина є носієм багатьох потенційних здібностей. Н. Чепелева наголошувала, що майбутньому психологу необхідна і сенситивність, інакше кажучи, чутливість. Якщо ви добре відчуваєте настрій іншої людини, вмієте здогадатися про її потреби, відчуваєте біль і радість близьких як власні, отже, ви володієте ще однією важливою якістю. Потрібно сказати, що вона, взагалі розвивається, але її початковий рівень має значення [7].

За даними Н. Аминова і М. Молоканова [1], дляпсихологазпрактичноюорієнтацієювиявилися характерними: виражена готовність до контактів; загальна інтелектуальність; вміння підтримувати контакти, тобто стресостійкість у процесі спілкування; вміння контролювати свою поведінку, тобто зберігати емоційний самоконтроль у процесі спілкування; атракція (привабливість); емоційна заразливість; емпатія; опора на себе в прийнятті рішень.

Наш інтерес до проблеми духовного потенціалу сучасної молоді викликаний насамперед її складністю. Жодна психологічна проблема не отримала такої широкої і всебічної уваги, як духовність, і у жодній проблемі немає стількох «білих плям», як у проблемі духовності [4].

Для сучасної молоді навчання у ВНЗ є одним із важливих етапів життєдіяльності, особистісного і професійного зростання. У цей період розкриваються потенційні якості та можливості, вдосконалюється інтелект, трансформується система ціннісних орієнтацій, відбувається розвиток професійних здатностей у зв'язку з опануванням фаху. Саме тому нами було проведене дослідження на базі ОНУ імені І.І. Мечникова, позаяк уже багато років він несе високу ланку підготовки фахівців, які успішно реалізуються в практичній і дослідницькій діяльності.

На базі ОНУ імені І.І. Мечникова на першому етапі нашого дослідження було проведено пілотажний експеримент, мета якого - ретроспективно оглянути професійні якості майбутніх фахівців-психологів. В експерименті брав участь 31 реципієнт віком від 15 до 25 років - студенти соціально-економічного коледжу ОНУ та студенти ФПСР.

У результаті пілотажного дослідження ми можемо сказати, що тільки незначна кількість реципієнтів (2\%) навчається, підтримуючи модні тенденції та для підтримки престижу соціальної ніші, і це нас може тільки тішити. У зв'язку з оглядом наукової літератури та проведеними методиками ми продовжуємо дослідження. I завдяки методу лангітюду ми зможемо порівняти ті якості, з якими реципієнти прийшли в університет, з набутими в період навчання [3].

Професіоналізація в психологічній сфері діяльності виступає, як указує О. Бондаренко, не тільки процесом входження й освоєння про- 
фесії, але й одночасно здійсненням особистісного та професійного саморозвитку, формуванням норм, мети, змістів професії та засобів їх досягнення. Якість і успішність професійної діяльності психолога насамперед залежить від того, чи зможе студент-психолог, перебуваючи в освітньому просторі, побудувати власну модель професійної діяльності, яка включатиме не тільки впевнене володіння технологією професійної діяльності, але й ціннісно-рольове бачення майбутньої професії та себе в ній [5].

На основі отриманих результатів у пілотажному експерименті нами було продовжено дослідження. Студенти 1-го курсу спеціальності «психологія» післядипломного навчання, які вже мають першу освіту, дали згоду і були нашими реципієнтами. Всього брали участь 32 особи.
Згідно з нашою метою нами була обрана та застосована методика «Шкала емоціонального відгуку» А. Меграбяна та виявлені такі результати у наших реципієнтів: $37,5 \%$ - дуже високий рівень емпатії; 46,8\% - високий рівень емпатії; 12,5\% - нормальний рівень емпатії; 3,1\% - низький рівень емпатії.

Високий рівень емоційного відгуку, який превалює у наших реципієнтів, на наш погляд, оголює одну з граней духовного потенціалу людини - емпатичність, яка має бути присутня у майбутніх фахівців-психологів, які надалі будуть працювати в межах концепції «людина-людина». На основі отриманих результатів ми зробили висновок, що реципієнти як майбутні фахівці мають ризик професійного «вигорання».

Проводячи опитування Кеннета Томаса «Визначення способів регулювання конфлік-

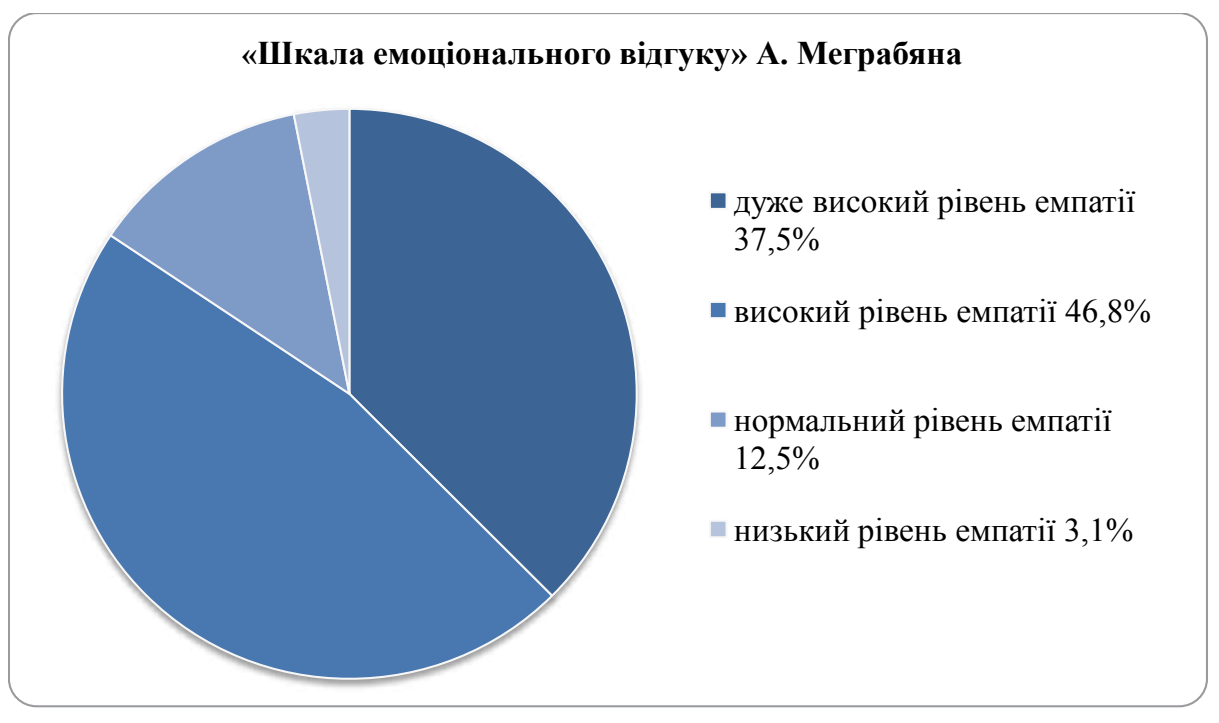

Рис. 1. «Шкала емоціонального відгуку» А. Меграбяна

В.Ф. Ряховський «Методика оцінки рівня тривожності»

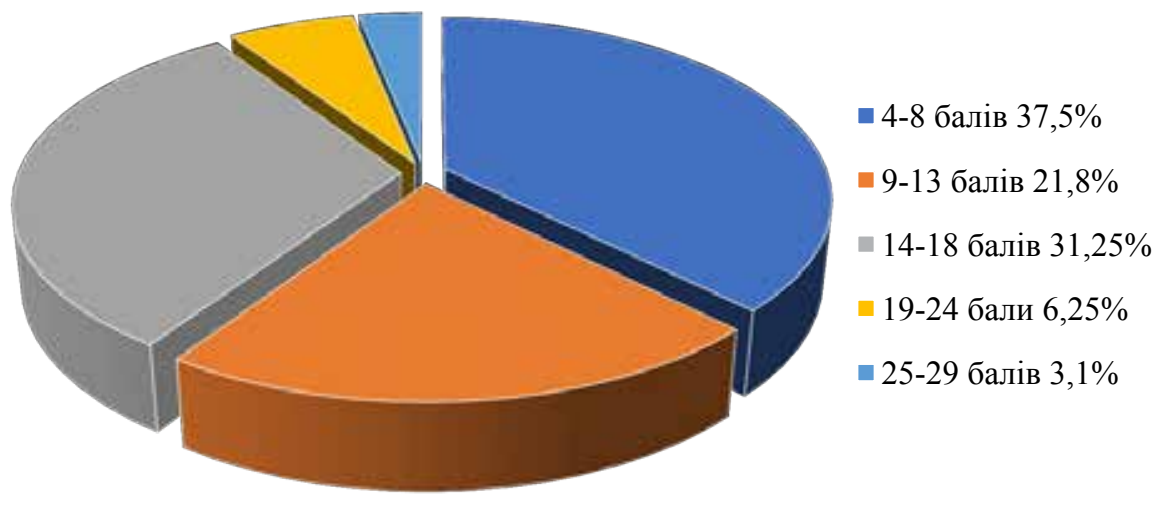

Рис. 2. В.Ф. Ряховський «Методика оцінки рівня тривожності» 
тів», ми отримали такі результати: середній бал за кожним типом: суперництво - 15,6\%; співробітництво - 84,3\%; компроміс - 68,75\%; уникнення - 50\%; пристосування $-31,25 \%$. Це підтверджує нашу гіпотезу, що фахівець-психолог має бути чуйним, емпатичним, неконфліктним, вміти співпрацювати з оточенням.

Застосувавши методику В. Раховського «Методика оцінки рівня товариськості», ми отримали такі результати: 4-8 балів тривожності отримали 37,5\%; 9-13 балів тривожності - 21,8\%; $14-18$ балів тривожності -31,25\%; 19-24 бали тривожності - 6,25\%; 25-29 балів тривожності - 3,1\%.

Отримані результати показують, що реципієнти вельми комунікабельні. I їхня комунікабельність не носить хворобливого характеру, що теж $є$ значущим для нашого дослідження. На основі отриманих результатів за методиками та відповідей, які ми отримали під час індивідуальної бесіди, нами було розроблено авторський опитувальник «Прагнення до світла», пріоритетними питаннями в якому були такі як: Чому Ви обрали професію психолога?; Якими якостями, на Вашу думку, повинен володіти психолог?; Хто з психологів для Вас кумир і чому?; Що Ви робите для підвищення професіоналізму?; що би Ви хотіли ще зробити для підвищення професіоналізму?; Ви проходили або проходите особисту терапію?

Здебільшого відповідями на наші відкриті питання були: здобути освіту - 87,5\%, зрозуміти світ - 62,5\%, допомогти іншим - 53,1\%, допомогти собі - 40,6\%, «краще орієнтуватися в суспільстві» - 37,5\%, зробити світ кращим - 34,3\%, допомогти близьким - 25\%, «бізнес-ідеї»-3,1\%.

Результати за другим питанням такі: рівновага - 96,8\%; інтелектуальні здібності - 87,5\%; емпатічность (чуйний, чуттєвий, співчуваючий) - 68,7\%; життєрадісність (позитивний настрій) - 46,8\%; духовний (усвідомлений) - 21,9\%; добродушний - 15,6\%; вольові якості (дисципліна, терпіння, витримка) 12,4\%; любить свою роботу - 9,37\%; досвідчений - 9,37\%; творчий - 9,37\%; а також по одній відповіді: чарівний, гнучкий, впевнений у собі, відкритий, з хорошим почуттям гумору, що поважає себе.

Отримані результати були проаналізовані методом контент-аналізу, що надає нам право зробити висновки, що в пріоритеті духовний потенціал виявлено в кожному, але в «зародковому» стані.
На наш погляд, духовний стан особистості психолога виявився характерними якостями, такими як: врівноваженість; загальна інтелектуальність; безпристрасність; вміння підтримувати контакти, тобто стресостійкість у процесі спілкування; вміння контролювати свою поведінку, тобто зберігати емоційний самоконтроль у процесі спілкування; атракція (привабливість); конгруентність; емоційна заразливість; емпатія; життерадісність .

Ці якості фундаментально впливають на психічне здоров'я людини, оптимізують ії життя, призводять до психічного та особистісного розвитку. Для свого функціонування душа (психіка, особистість) потребують енергії, джерелом якої стає духовна сфера як невичерпне джерело.

У зв'язку з оглядом наукової літератури та проведеними методиками ми продовжуємо дослідження. I завдяки методу лангітюду ми зможемо порівняти ті якості, з якими реципієнти прийшли в університет, 3 набутими в період навчання.

\section{ЛІТЕРАТУРА:}

1. Амінів Н.А., Молоканов М.В. Про компоненти спеціальних здібностей майбутніх шкільних психологів. Психологічний журнал. 1992. Т. 13. № 5. С. 108.

2. Боришевський М.Й. Духовність особистості у процесі соціалізації. Актуальність проблеми психології: Психологія навчання. Генетична психологія. Медична психологія / За ред. С.Д. Максименко, М.В. Папучі. Київ-Ніжин, 2008. Том 10. Вип. 6. С. 12-16.

3. Данілова О.С. «Соціальна концепція» ікони індикатор духовності: експериментальні дослідження. Вісник Одеського національного університету. 25.12.2007. Том 12. Вип. 16: Психологія. С. 4-11.

4. Danilova E.S., Shchebliuk O.I. The phenomenon of spiritual growth of modern youth. Man and environment, trends and prospects : Abstracts of III International Scientific and Practical Conference. SH SCW "NEW ROUTE". Tokyo, Japan. 2020. Pp. 191-193.

5. Овсянецька Л.П. До проблеми психологічної сутності домагань особистості. Філософрія, соціологія, психологія. Івано-Франківськ : Прикарпатський ун-т ім. В. Стесраника, 1999. Вип. 3. № 1. С. 55-62.

6. Савчин М.В. Духовний потенціал людини : навчальне видання : монограсрія. Вид. 2-ге, пер., доп. Івано-Франківськ : Місто НВ, 2010. 508 с.

7. Чепелева Н.В. Формування професійної компетентності в процесі вузівської підготовки психолога-практика. Актуальні проблеми психології. Київ : Інститут психології АПН України. 1999. С. 271-279. 